\title{
Total sulphur contents over a three-year period in different organic vineyards of Apulia region, South-Eastern Italy
}

\author{
Maria Rosaria Provenzano, ${ }^{1}$ Hamid El Bilali, ${ }^{1}$ Vito Simeone, ${ }^{2}$ Donato Mondelli, ${ }^{1}$ \\ Nuray Baser ${ }^{2}$ \\ 1Dipartimento di Biologia e Chimica Agro-Forestale e Ambientale, University of Bari; \\ 2Mediterranean Agronomic Institute of Bari, Valenzano, Bari, Italy
}

\begin{abstract}
Sulphur (S) is one of the most important pillars of pest control in organic viticulture. In organic vineyards, sulphur is used mainly for the control of grapevine powdery mildew. Grapevine is widely grown organically in Apulian farms. The objective of the work was to evaluate total sulphur concentrations with ICP-OES in four Apulian organic vineyard over a three-year period. Total sulphur contents were determined also in other fields such as olive groves and a pasture where no sulphur had been used. The highest values were found in the organic vineyards where the smallest quantities of sulphur were used. No relationship was found between sulphur applications and its effective accumulations. A decrease of $\mathrm{S}$ concentrations was observed in the vineyard where the highest quantity of sulphur was used in 2005 and 2006 growing seasons whereas an increase was observed in the field where relatively low quantities had been applied. Furthermore, total S concentrations were higher in the control fields where no sulphur-based treatments had been performed. Results obtained indicated that many factors must be taken into account while considering sulphur turnover, the most important of which are soil management, climate and crop growth pattern. A positive correlation was found between total S concentrations and organic mat-
\end{abstract}

Correspondence: Maria Rosaria Provenzano, Dipartimento di Biologia e Chimica Agro-Forestale e Ambientale, University of Bari, via G. Amendola 165/a, 70126 Bari, Italy.

Tel. +39.080 .5442929 - Fax: +39.080 .5442830 .

E-mail: provenza@agr.uniba.it

Key words: total sulphur; organic vineyards; accumulation

Acknowledgements: funding for this work was provided by the University of Bari and the Mediterranean Agronomic Institute of Bari (IAM-B) under the European Community initiative Interreg III A Italy-Albania 2000-2006: Integrated project for the diffusion and technical assistance in the implementation of methodologies for the production of organic products (PAB). The authors thank the farmers involved for their valuable contributions to this research.

Received for publication: 7 April 2011.

Accepted for publication: 22 August 2011.

(C) Copyright M.R. Provenzano et al., 2011

Licensee PAGEPress, Italy

Italian Journal of Agronomy 2011; 6:e27

doi:10.4081/ija.2011.e27

This work is licensed under a Creative Commons Attribution NonCommercial 3.0 License (CC BY-NC 3.0). ter contents. Our results, although confined into a relatively short period of time, underlined the urgent need for further investigations to follow sulphur long-term dynamics in the Mediterranean soils.

\section{Introduction}

Sulphur is the $10^{\text {th }}$ abundant element (Stevenson and Cole, 1999), and is an essential element in the life processes of all living things including micro-organisms, higher plants, animals, and humans (Rehm and Schmitt, 1989). Some authors consider it as a macronutrient for all plants being as important as nitrogen, phosphorus, and potassium. It is described as a secondary plant nutrient only because it is not as often deficient as them (Schulte and Kelling, 1992). Crops requirements in sulphur range from 10 to $50 \mathrm{~kg} / \mathrm{ha}^{-1}$ (Gessa and Ciavatta, 2005; Zhao et al., 1996).

In Apulia region (south-eastern Italy), organic agriculture represents $6.9 \%$ of the regional agricultural area whereas it represents $9 \%$ of the Italian organic land. Olive groves covers $28 \%$ ( $23,258 \mathrm{ha})$ and vineyards $3 \%$ (2888 ha) of the regional organic agriculture surface, respectively (Pugliese, 2006). Sulphur is one of the most important pillars of pest control in organic agriculture. In organic vineyards, it is used mainly for the control of grapevine powdery mildew caused by Erysiphe necator (Mildura, 2003). In case of favourable conditions, an average on 12 treatments are performed in Apulian organic vineyards during each cropping season. These treatments are generally conducted using formulations containing $80 \%$ of sulphur at the application rate of $4 \mathrm{~kg} \mathrm{ha}^{-1}$. That is to say that about $36 \mathrm{~kg} \mathrm{ha}^{-1}$ of sulphur are brought each year to organic vineyards under wettable form. In case of high pressure of the disease, coinciding with bunches closure phenological developmental stage, dust sulphur is used in one or two treatments reaching in this case up to $40 \mathrm{~kg} \mathrm{ha}^{-1}$. Therefore, the quantity of sulphur applied to organic vineyards in Apulia can reach more than $70 \mathrm{~kg} \mathrm{ha}^{-1} \mathrm{yr}^{-1}$ (Provenzano et al., 2006). From the total quantity of sulphur used in each treatment, only a part reaches the target (pest on leaves and other plants organs depending on foliage surface characteristics such as cuticle, wax, etc.) while a certain fraction, more or less relevant, is deposited on soil or lost as air drift. The fraction reaching the soil depends on chemical and physical characteristics of the formulations (e.g. vapour pressure), spray volume, and spraying methods (drops size, spraying pressure, etc.). In general, the bigger the drops size the less adsorbed they become thus increasing the probability that they reach the soil. Climatic conditions play a major role mainly as far as wind speed is concerned (Matthews, 2006).

The European Council regulation 834/2007 on organic agriculture did not fix any threshold for sulphur use while that was done in the case of copper. Products allowed for plant protection purposes in organic farms 
have normally very low environmental and human health impacts. However, few information are available on environmental impact of sulphur on soils in the Mediterranean area in general and Apulia region in particular. Several studies focused on the long-term management and cropping impacts on soil sulphur especially in the temperate zones (Solomon et al., 2001; Zucker and Zech, 1985; Bettany et al., 1980; Tabatabai and Bremner, 1972). However, to our knowledge, no exhaustive and comprehensive study has been carried out so far on the impact of sulphur-based treatments on sulphur accumulation in Mediterranean organic vineyards soils.

The objective of this research is to evaluate total sulphur concentrations in some Apulian organic vineyards over a three-year period with the aim to study the impact of sulphur-based treatments on sulphur contents in Mediterranean vineyards soils.

\section{Materials and Methods}

During April and May 2005, 2006 and 2007, before organic farmers started treatments during the new vine growing seasons, soil samples were collected at 0-0.2 m and 0.2-0.4 m depths in four organic vineyards in Apulia region: i) Mediterranean Agronomic Institute of Bari (IAM-B) experimental field divided into two vineyards of $1160 \mathrm{~m}^{2}$ each. The first one is dedicated to three table grape varieties: Italia, Victoria, and Red Globe. The second one is dedicated to four wine grape cultivars: Chardonnay, Negroamaro, Primitivo, and Uva di Troia; ii) Papparicotta, a 100 ha farm with an Uva di Troia vineyard; iii) Pietrarossa vineyard covering a surface of $3500 \mathrm{~m}^{2}$ and divided into two fields with two different varieties: Primitivo and Chardonnay; iv) La Pizzica farm extending over 130 ha and featuring a cherry orchard, olive groves, cereals fields, and a pasture. The vineyard covers 3.4 ha. Cabernet Sauvignon is grown on two hectares and the remaining surface is dedicated to Croatino.

Four sub-samples were retrieved in each field (vineyard, olive grove, etc.) from each sampling site which were bulked to obtain a representative sample for the site. In 2005, sampling points were referenced in order to sample soils from the same points during the following years (2006 and 2007). Only in 2006 and only in the IAM-B experimental organic vineyard soil samples were collected at three different depths: 0-0.05, $0-0.2$ and $0.2-0.4 \mathrm{~m}$ in order to study the vertical distribution of total $\mathrm{S}$ along the soil profile.

In order to estimate the background/baseline total $\mathrm{S}$ concentrations and ascertain the extent of sulphur accumulation in organic vineyards due to sulphur treatments, in each farm soil samples were also collected, at the same depths, from olive groves where sulphur is not used. In the case of La Pizzica farm, a pasture field, on which sulphur was never used, was considered as a control.

All soil samples were air-dried at greenhouse temperature (approximately $25-30^{\circ} \mathrm{C}$ ), lightly ground, mixed thoroughly in order to homogenise them, and sieved through a $2 \mathrm{~mm}$ stainless steel sieve. Homogenized samples were sealed in polyethylene bags and then stored in refrigerator for further analyses. All analyses were performed on the size fraction smaller than $2 \mathrm{~mm}$. Soil chemical analyses were performed in accordance with internationally recommended and accepted analysis procedures and/or Italian official methods (MiPAAF, 1999).

Particles sizes distribution was determined using the pipette method (Gee and Bauder, 1986), after dispersion of soil samples with sodium hexametaphosphate and sodium carbonate solutions. Textural classes were determined in accordance with USDA classification. Soil pH was measured by a glass electrode (Crison Basic $20^{\circledR}$ ) in distilled water using a suspension 1:2.5 soil to liquid phase ratio. Organic carbon was determined by Walkley and Black method modified by Jackson (1958). Total carbonate was determined using a volumetric method based on its dissolution by hydrochloric acid (HCl) followed by measurement in Dietrich-
Fruehling calcimeter.

Total sulphur concentrations were determined in 2005, 2006, and 2007 on digested soil samples filtrates with an optical emission spectrometer (Thermo Electron ICAP 3000) using a wavelength equal to $182.03 \mathrm{~nm}$. Soil samples digestion was carried out as follows: $0.5 \mathrm{~g}$ of fine soil were put in $50 \mathrm{~mL}$ Teflon vessels with $3.0 \mathrm{~mL}$ of nitric acid (HNO3), 75\%, 1.0 $\mathrm{mL}$ of hydrochloric acid $(\mathrm{HCl}) 37 \%$ and $1.0 \mathrm{~mL}$ of oxygen peroxide $\left(\mathrm{H}_{2} \mathrm{O}_{2}\right)$ $30 \%$ then the whole was digested in a microwave oven (CEM, MarsX Press): $3 \mathrm{~min}$ at $140^{\circ} \mathrm{C} ; 3 \mathrm{~min}$ at $165^{\circ} \mathrm{C}$, and $20 \mathrm{~min}$ at $190^{\circ} \mathrm{C}$. Soil extracts were filtered with Whatman 42 . All chemicals used were of analysis grade and purchased from Aldrich (Sigma-Aldrich, Milan, Italy).

Sulphur concentrations were analysed by one-way analysis of variance (ANOVA) and Student's $t$-test. Duncan test was used for multiple range comparisons/separation of means. Significant differences were determined at a significance level equal to or lower than 5\%. Linear regressions were used to test relationships between various soil properties (organic matter, clay, $\mathrm{pH}$, and carbonate) and total sulphur concentrations. Correlation analyses were performed using the Least Squares method. An SPSS (Statistical Package for the Social Sciences) software version (SPSS 12.0 for Windows) was used to carry out all above-mentioned statistical tests.

\section{Results and Discussion}

\section{Soils physico-chemical properties}

Chemical and physical properties of soil samples considered in this work are illustrated in Table 1. All vineyards soils had loamy textures according to USDA classification. $\mathrm{pH}$ values were all around 8 thus confirming that Apulian soils are mainly alkaline. Total carbonate showed a high variability from a farm to another.

\section{Sulphur use and total sulphur concentrations in the organic vineyards}

Total quantities of $\mathrm{S}$ applied to each organic vineyard during the growing seasons 2004-2006 are presented in Table 2. Over the years 20042006 the highest sulphur quantity was used in Papparicotta organic vineyard (221 $\left.\mathrm{kg} \mathrm{ha}^{-1}\right)$ while the lowest was applied to La Pizzica vineyard $\left(31 \mathrm{~kg} \mathrm{ha}^{-1}\right)$.

In 2005, a high variability of total sulphur concentrations was evident in the organic farms. The highest variability (expressed as standard error) was observed in La Pizzica farm, that was also characterised by the highest variability of organic matter contents. The lowest variability was found in IAM-B experimental fields characterized by a more homogeneous soil especially as far as organic matter content is concerned. Concerning the 0-0.2 m layer, average total sulphur concentrations were $500 \mathrm{mg} \mathrm{kg}^{-1}$ in La Pizzica vineyard - where the smallest quantities of sulphur were used in $2004-366 \mathrm{mg} \mathrm{kg}^{-1}$ in Papparicotta, $380.9 \mathrm{mg} \mathrm{kg}^{-1}$ in Pietrarossa, and $409 \mathrm{mg} \mathrm{kg}^{-1}$ in the IAM-B vineyard. Regarding the 0.2 $0.4 \mathrm{~m}$ layer, they resulted $376.5 \mathrm{mg} \mathrm{kg}^{-1}$ in the IAM-B experimental fields and $331.1 \mathrm{mg} \mathrm{kg}^{-1}$ in Papparicotta vineyard (Figure 1).

In 2006, in the 0-0.2 m layer, total S concentrations were $496.2 \mathrm{mg} \mathrm{kg}^{-1}$ in La Pizzica vineyard; $417.7 \mathrm{mg} \mathrm{kg}^{-1}$ in Pietrarossa, $399.3 \mathrm{mg} \mathrm{kg}^{-1}$ IAM$\mathrm{B}$; and $360.5 \mathrm{mg} \mathrm{kg}^{-1}$ in Papparicotta. Regarding the 0.2-0.4 m layer, concentrations were $326.1 \mathrm{mg} \mathrm{kg}^{-1}$ in Papparicotta and $414.0 \mathrm{mg}^{-1}$ in Pietrarossa vineyard (Figure 2).

Results obtained in 2007 confirmed data observed in the previous years. In fact, in the 0-0.2 m layer, total S concentrations were $485.8 \mathrm{mg}$ $\mathrm{kg}^{-1}$ in La Pizzica and, only, $376.5 \mathrm{mg} \mathrm{kg}^{-1}$ in Papparicotta vineyard. Whereas in the 0.2-0.4 sampling layer, $S$ concentrations resulted $337.8 \mathrm{mg}$ $\mathrm{kg}^{-1}$ in Pietrarossa and $412.7 \mathrm{mg} \mathrm{kg}^{-1}$ in La Pizzica vineyard (Figure 3). 


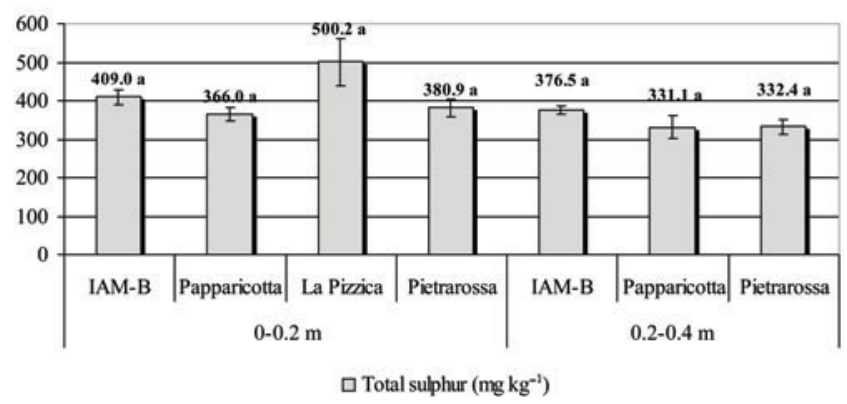

Figure 1. Total sulphur concentrations in the four sampled Apulian organic farms, 2005. Averages were calculated considering all the samples collected at the same depth in each farm. No soil samples were collected from La Pizzica and Pietrarossa farms at 0.2-0.4 $\mathrm{m}$ depth. Histograms with different letters are significantly different according to Duncan post-hoc test considering first risk value $\alpha<=5 \%$. Error bars represent standard errors of the means.

\section{Vertical distribution of sulphur in IAM-B experimental field}

Total S concentrations increased along the soil profile. However, no significant difference was highlighted between total sulphur concentrations in the three sampling depths according to Duncan post-hoc test ( $\mathrm{P}=0.761$ ) (Figure 4).

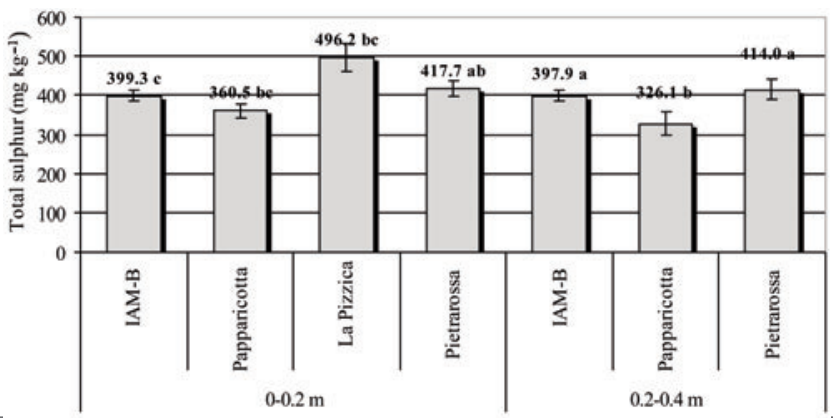

Figure 2. Total sulphur concentrations in the four sampled Apulian organic farms, 2006. Averages were calculated considering all the samples collected at the same depth in each farm. Histograms with different letters are significantly different according to Duncan multiple range test considering first risk value $\alpha<=5 \%$. Statistical analysis regards total sulphur concentrations in the sampled farms in each sampling depth. No soil samples were collected from La Pizzica farm at 0.2-0.4 depth. Error bars represent standard errors of the means.

\section{Comparison between quantities of sulphur applied and its accumulation in each sampled farm}

In Figure 5 a comparison between the quantities of sulphur used during the growing seasons 2005 and 2006 and its accumulation in the sampled organic vineyards in the 0-0.2 m layer is illustrated. Sulphur accumulation in each vineyard was calculated as the mean of differences in

Table 1. Soil physico-chemical properties. Averages were calculated considering all the samples collected at the same depth in each field (i.e. vineyard, olive grove, pasture). Values were expressed as means \pm standard errors.

\begin{tabular}{|c|c|c|c|c|c|c|c|}
\hline Farm & Crop & $\begin{array}{l}\text { Depth } \\
\text { (m) }\end{array}$ & $\begin{array}{c}\text { Clay } \\
\left(\mathrm{g} \mathrm{kg}^{-1}\right)\end{array}$ & $\begin{array}{c}\text { Texture class } \\
\text { (USDA) }\end{array}$ & $\begin{array}{l}\mathrm{pH}_{\mathrm{H} 20} \\
(1: 2.5)\end{array}$ & $\begin{array}{l}\text { Organic matter } \\
\qquad\left(\mathrm{g} \mathrm{kg}^{-1}\right)\end{array}$ & $\begin{array}{l}\text { Total carbonate } \\
\qquad\left(\mathrm{g} \mathrm{kg}^{-1}\right)\end{array}$ \\
\hline \multicolumn{8}{|l|}{ IAM-B } \\
\hline & $\begin{array}{l}\text { Vine } \\
\text { Olive }\end{array}$ & $\begin{array}{c}0-0.2 \\
0.2-0.4 \\
0-0.2 \\
0.2-0.4\end{array}$ & $\begin{array}{l}215 \\
233 \\
244 \\
276\end{array}$ & $\begin{array}{l}\text { Loam } \\
\text { Loam } \\
\text { Silt loam } \\
\text { Silt loam }\end{array}$ & $\begin{array}{l}8.0 \pm 0.0 \\
8.0 \pm 0.0 \\
7.9 \pm 0.0 \\
8.2 \pm 0.2\end{array}$ & $\begin{array}{l}25.8 \pm 0.5 \\
20.7 \pm 0.7 \\
30.5 \pm 0.6 \\
23.7 \pm 0.3\end{array}$ & $\begin{array}{c}197 \pm 22.1 \\
228 \pm 22.2 \\
38 \pm 3.4 \\
39 \pm 6.6\end{array}$ \\
\hline Papparicotta & $\begin{array}{l}\text { Vine } \\
\text { Olive }\end{array}$ & $\begin{array}{c}0-0.2 \\
0.2-0.4 \\
0-0.2 \\
0.2-0.4\end{array}$ & $\begin{array}{l}174 \\
183 \\
129 \\
141\end{array}$ & $\begin{array}{l}\text { Loam } \\
\text { Loam } \\
\text { Silt loam } \\
\text { Silt loam }\end{array}$ & $\begin{array}{l}8.2 \pm 0.0 \\
8.1 \pm 0.0 \\
8.0 \pm 0.0 \\
8.0 \pm 0.1\end{array}$ & $\begin{array}{l}17.4 \pm 0.4 \\
21.2 \pm 0.6 \\
26.1 \pm 1.1 \\
26.6 \pm 0.5\end{array}$ & $\begin{array}{c}262 \pm 37.0 \\
261 \pm 37.6 \\
142 \pm 12.0 \\
131 \pm 9.7\end{array}$ \\
\hline La Pizzica & $\begin{array}{c}\text { Vine } \\
\text { Olive } \\
\text { Pasture }\end{array}$ & $\begin{array}{c}0-0.2 \\
0.2-0.4 \\
0-0.2 \\
0.2-0.4 \\
0-0.2 \\
0.2-0.4\end{array}$ & $\begin{array}{l}204 \\
222 \\
151 \\
214 \\
203 \\
282\end{array}$ & $\begin{array}{l}\text { Loam } \\
\text { Loam } \\
\text { Loam } \\
\text { Loam } \\
\text { Silt loam } \\
\text { Clay loam }\end{array}$ & $\begin{array}{l}8.2 \pm 0.0 \\
8.3 \pm 0.0 \\
8.3 \pm 0.0 \\
8.3 \pm 0.1 \\
7.9 \pm 0.1 \\
8.3 \pm 0.1\end{array}$ & $\begin{array}{l}33.6 \pm 2.5 \\
12.5 \pm 1.4 \\
21.1 \pm 2.9 \\
16.2 \pm 3.0 \\
47.8 \pm 0.5 \\
39.1 \pm 0.5\end{array}$ & $\begin{array}{c}291 \pm 32.0 \\
464 \pm 29.3 \\
472 \pm 52.7 \\
538 \pm 85.1 \\
28 \pm 2.8 \\
99 \pm 8.7\end{array}$ \\
\hline Pietrarossa & $\begin{array}{l}\text { Vine } \\
\text { Olive }\end{array}$ & $\begin{array}{c}0-0.2 \\
0.2-0.4 \\
0-0.2 \\
0.2-0.4\end{array}$ & $\begin{array}{l}181 \\
260 \\
166 \\
344\end{array}$ & $\begin{array}{c}\text { Loam } \\
\text { Loam } \\
\text { Silt loam } \\
\text { Silty clay loam }\end{array}$ & $\begin{array}{l}7.9 \pm 0.0 \\
8.0 \pm 0.0 \\
7.8 \pm 0.0 \\
7.9 \pm 0.0\end{array}$ & $\begin{array}{l}29.6 \pm 1.2 \\
19.2 \pm 0.8 \\
34.8 \pm 2.3 \\
24.7 \pm 0.7\end{array}$ & $\begin{array}{c}188 \pm 34.4 \\
157 \pm 29.9 \\
12 \pm 2.8 \\
7 \pm 1.1\end{array}$ \\
\hline
\end{tabular}

Table 2. Sulphur quantities used in the sampled organic vineyards during the period 2004-2006.

\begin{tabular}{|c|c|c|c|c|c|c|c|}
\hline Vineyard & Establishment & Conversion & First use of sulphur & $\begin{array}{r}\text { Annual si } \\
2004\end{array}$ & $\begin{array}{r}\text { Ir use } \\
2005\end{array}$ & $\begin{array}{c}\left.\mathrm{ha}^{-1} \mathrm{yr}^{-1}\right) \\
2006\end{array}$ & $\begin{array}{l}\text { Total sulphur }\left(\mathrm{Kg} \mathrm{ha}^{-1}\right) \\
\text { 2004-2006 }\end{array}$ \\
\hline IAM-B & 2003 & 2003 & 2004 & 30.0 & 80.4 & 41.6 & 152.0 \\
\hline Papparicotta & 1983 & 1998 & 1996 & 15.0 & 17.15 & 188.8 & 221.0 \\
\hline Pietrarossa & 1999 & 1999 & 2000 & 18.0 & 25.0 & 22.5 & 65.5 \\
\hline La Pizzica & 1982 & 1995 & 1996 & 10.0 & 17.2 & 4.0 & 31.0 \\
\hline
\end{tabular}


terms of total S concentrations in each sampling site between 2007 and 2005. No relationship was found between sulphur applications and its effective accumulations. A decrease of concentrations was observed in Papparicotta vineyard where the highest quantity of sulphur was used in 2005 and 2006 growing seasons whereas the increase in La Pizzica vineyard cannot be explained only considering the quantities of $\mathrm{S}$ applied. Climatic and geological conditions could have a direct influence on sulphur concentrations. Wang et al. (2006) found that soil sulphur concentrations significantly decreased with an increase in mean annual temperature in bulk soils of the native grassland and cultivated sites indicating that temperature is the most important site attribute governing soil organic sulphur pool turnover in the Great Plains of North America. Similar results were previously highlighted by Nichols (1984), and Amelung et al. (1998a;1999). Sulphur biogeochemical cycle is quite complex and sulphur turnover may be influenced by many other factors such as soil management and climate. In addition sulphur cycle in strongly related to that of soil organic matter. The warm and moist conditions characterizing irrigated Apulian vineyards could cause rapid decomposition of soil organic matter and subsequent sulphur uptake (as sulphate) by the crop and/or depletion via volatilization and leaching phenomena. In fact, a positive correlation was found between total $\mathrm{S}$ concentrations, calculated considering all the soil samples collected from the four sampled organic vineyards at the $0-0.4 \mathrm{~m}$ depth, and organic matter contents (Figure 6).

\section{Comparison of total sulphur accumulation between vineyard and untreated field in each sampled farm}

In order to evaluate the effects of $\mathrm{S}$ treatments, comparisons of total $\mathrm{S}$ concentrations in vineyards and untreated fields (olive groves and pasture in the La Pizzica farm) were made (Figure 7). Total S accumulation was higher in organic olive groves than in vineyards except in IAM-B farm. This result is quite unexpected since there was no external $S$ input via treatments in olive groves. Nevertheless, no statistically significant differences were highlighted between total sulphur accumulation in olive groves and vineyards neither in IAM-B farm ( $\mathrm{P}=0.926$ for $0-0.2$ and 0.520 for 0.2-0.4 layer), nor in Papparicotta farm $(\mathrm{P}=0.599)$, and $L a$ Pizzica farm $(\mathrm{P}=0.721)$. This result could be explained considering that crop growth as well as agronomic and cultural practices could influence organic matter content (Amelung et al., 1998a,b;1997; Burke et al., 1989) and that olive groves are less intensively cultivated than vineyards. Wang et al. (2006) indicated that, on the average, $30 \%$ of the original soil organic sulphur was depleted following the conversion of the native grassland to cultivated fields in Great Plains of North America. The loss of organic sulphur in the cultivated soils could be mainly attributed to physical disruption of soil aggregates and accelerated mineralization rate of soil organic matter as a result of increased aeration and exposure of originally inaccessible organic sulphur to soil micro-organisms (Amelung et al., 1998b).

\section{Conclusions}

In this research total sulphur concentrations were determined in some Apulian organic vineyards over a three-year period. The highest values were found in the organic vineyard where the smallest quantities of sulphur were used. Considering the distribution of $S$ evaluated in the $0-0.05,0-0.2$ and $0.2-0.4 \mathrm{~m}$ depths in the experimental field of the Mediterranean Agronomic Institute of Bari, concentrations were found to increase along the soil profile. When comparing total $\mathrm{S}$ accumulation, results showed that no relationship was found between sulphur applications and its effective accumulations. A decrease of concentrations was observed in the vineyard where the highest quantity of sulphur was used

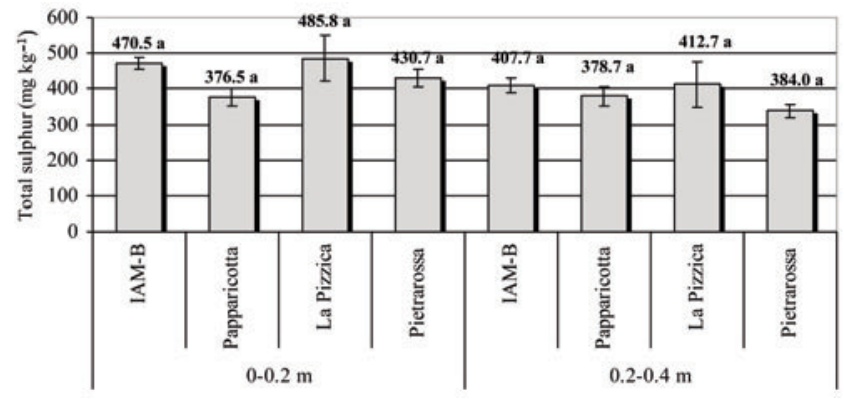

Figure 3. Total sulphur concentrations in the four sampled Apulian organic farms, 2007. Averages were calculated considering all the samples collected at the same depth in each farm. Histograms with different letters are significantly different according to Duncan multiple range test considering first risk value $\alpha<=5 \%$. Error bars represent standard errors of the means.

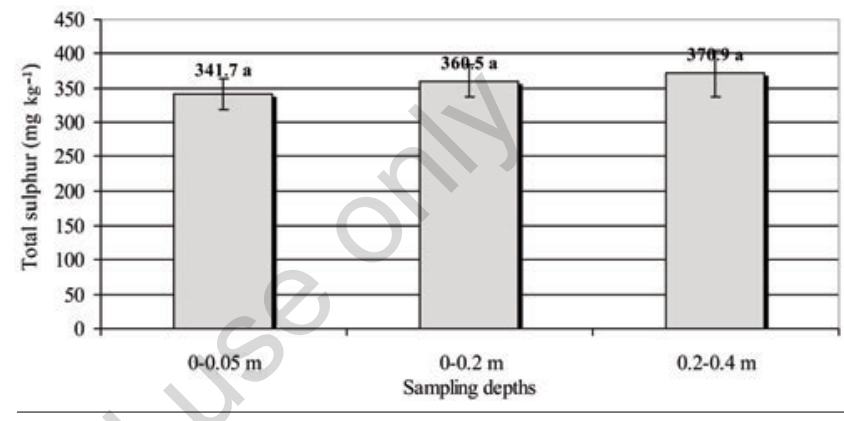

Figure 4. Sulphur vertical distribution in IAM-B organic vineyard at three depths: 0-0.05, 0-0.2, and 0.2-0.4 m. Histograms with different letters are significantly different according to Duncan multiple range test considering first risk value $\alpha<=5 \%$. Error bars represent standard errors of the means.

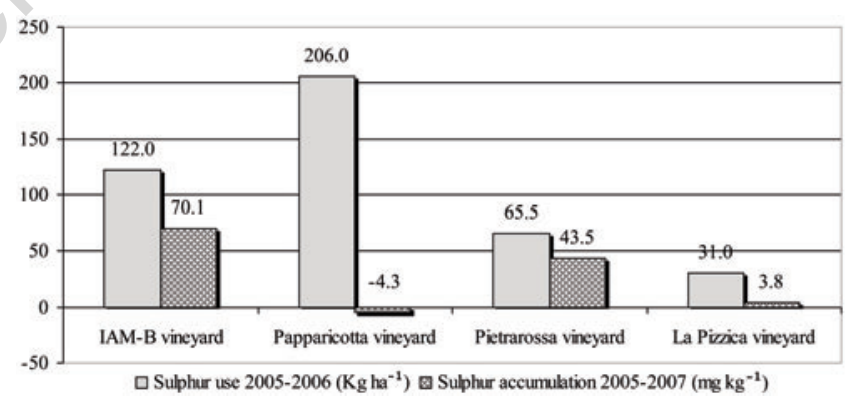

Figure 5. Comparison between sulphur use and its accumulation in the sampled organic vineyards in 0-0.2 $\mathrm{m}$ layer.

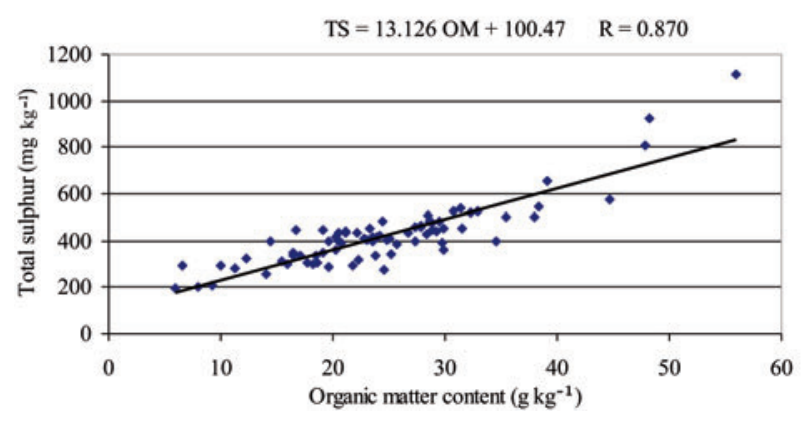

Figure 6. Correlation between total sulphur concentrations and organic matter contents. Correlations were calculated considering all the samples collected from the four sampled organic vineyards in the 0-0.4 m depth in 2007. TS, total sulphur concentrations $\left(\mathrm{mg} \mathrm{kg}^{-1}\right)$; $\mathrm{OM}$, organic matter contents $\left(\mathrm{g} \mathrm{kg}^{-1}\right) ; \mathrm{R}$, correlation coefficient. 


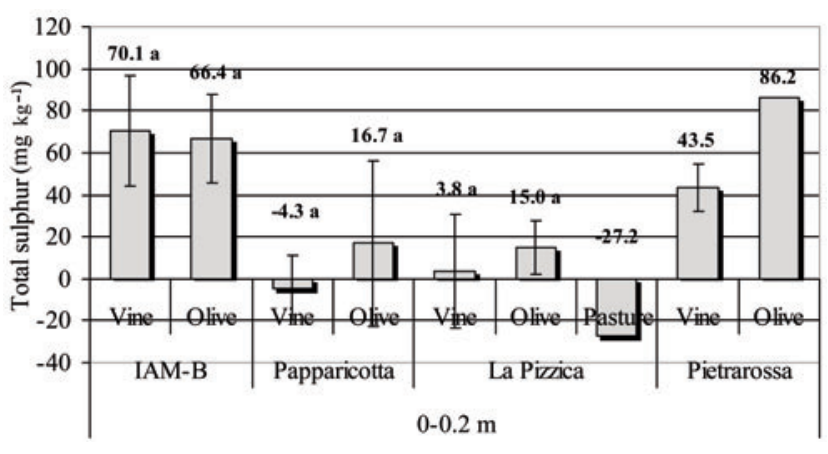

Figure 7. Comparison of total sulphur accumulation between vineyard and control field in each sampled farm in 2005-2007 period in the 0-0.2 $\mathrm{m}$ sampling depth. No statistical analysis was carried out on samples collected from Pietrarossa farm since the number of samples collected from the olive grove was low. Bars with different letters are significantly different according to Student's $t$-test considering first risk value $\alpha<=5 \%$. Bars represent standard errors of the means.

in 2005 and 2006 growing seasons whereas an increase was observed in the field where relatively low quantities had been applied. Furthermore, total $S$ concentrations were higher in the control fields where no sulphurbased treatments had been performed. Results obtained indicated that, considering that sulphur biogeochemical cycle is quite complex, many factors must be taken into account, the most important of which are soil management and climate. In fact, a positive correlation was found between total $\mathrm{S}$ concentrations and organic matter contents. Consequently, since the warm and moist conditions characterizing irrigated Apulian vineyards could cause rapid decomposition of soil organic matter, sulphur uptake (as sulphate) by the crop and/or depletion for volatilization and leaching phenomena must be considered. Our results, although confined into a relatively short period of time, underline the urgent need for further investigations to follow sulphur long-term dynamics in the Mediterranean soils taking into consideration soil management practices, (micro)-climatic conditions as well as vine growth and development patterns.

\section{References}

Amelung W., Flach K.W., Zech W., 1997. Climatic effects on soil organic matter composition in the Great Plains. Soil Sci. Soc. Am. J. 61:115123.

Amelung W., Flach K.W., Zech W., 1999. Neutral and acidic sugars in particle-size fractions as influenced by climate. Soil Sci. Soc. Am. J. 63:865-873.

Amelung W., Flach K.W., Zhang X., Zech W., 1998b. Climatic effects on C pools of native and cultivated prairie. Adv. GeoEcol. 31:217-224.

Amelung W., Zech W., Zhang X., Follett R.F., Tiessen H., Knox E., Flach K.W., 1998a. Carbon, nitrogen and sulfur pools in particle-size fractions as influenced by climate. Soil Sci. Soc. Am. J. 62:172-181.

Bettany J.R., Saggar S., Stewar, J.W.R., 1980. Comparison of the amounts and forms of sulfur in soil organic matter fractions after 65 years of cultivation. Soil Sci. Soc. Am. J. 44:70-75.

Burke I.C., Yonker C.M., Parton W.J., Cole C.V., Flach K., Schimel D.S.,
1989. Texture, climate, and cultivation effects on soil organic matter content in U.S. grassland soils. Soil Sci. Soc. Am. J. 53:800-805.

Gee G.W., Bauder J.W., 1986. Particle size analysis. In: A. Klute (ed.) Methods of Soil Analysis, Part 1. Physical and Mineralogical Methods. Agronomy Monograph N. 9, American Society of Agronomy, Soil Science Society of America, Madison, WI, USA.

Gessa C.E., Ciavatta C., 2005. Gli elementi nutritivi - Zolfo. In: P. Sequi (ed) Fondamenti di chimica del suolo. Pàtron Ed., Bologna, Italy.

Jackson M.L., 1958. Soil chemical analysis. Prentice Hall Inc., Englewood Cliffs, NJ, USA.

Matthews G.A., 2006. Pesticides: Health, safety and the environment. Blackwell Publishing, Berkshire, UK.

Mildura D.M., 2003. Organic Farming: Managing grapevine powdery mildew. Department of Primary Industries, Victoria, Australia. Accessed on: 30 August 2005. Available from: http:/www.vic.gov.au

Ministry of Agricultural, Food and Forestry Policies, 1999. Metodi ufficiali di analisi chimica del suolo. Decreto Ministeriale del 13 settembre 1999. Official Journal Supplement no. 284, 21/10/1999.

Nichols J.D., 1984. Relation of organic carbon to soil properties and climate in the Southern Great Plains. Soil Sci. Soc. Am. J. 48:13821384.

Provenzano M.R., El Bilali H., Simeone V., Baser N., 2006. Influenza delle caratteristiche chimico-fisiche del suolo e della gestione fitosanitaria sulla concentrazione di zolfo in oliveti e vigneti biologici della Puglia. pp 120-129 in Atti XXIV Convegno Nazionale della Società Italiana di Chimica Agraria, Alghero, SS, Italy.

Pugliese P., 2006. L'agricoltura biologica in Puglia: non solo cifre... Accessed on: 14 February 2008. Available from: http:/www.premiobiol.it/documenti/2006_ita_ _ AB\%20in\%20Puglia.pdf?PHPSES$\mathrm{SID}=918 \mathrm{~b} 0 \mathrm{a} 40 \mathrm{~b} 0 \mathrm{~d} 3 \mathrm{c} 209 \mathrm{~b} 622 \mathrm{c} 5 \mathrm{c} 87 \mathrm{ff} 8 \mathrm{e} 817$

Rehm G., Schmitt M., 1989. Sulphur for Minnesota soils. Communication and Educational Technology Services, University of Minnesota Extension Service. Accessed on: 8 August 2005. Available from: http://www.extension.umn.edu/distribution/cropsystems/ DC0794.html

Schulte E.E., Kelling K.A., 1992. Soil and applied sulphur. Understanding plant nutrients; A2525. University of Wisconsin-Madison and University of Wisconsin-Extension, Cooperative extension. Accessed on: 10 August 2005. Available from: http://cecommerce.uwex.edu /pdfs/A2525.PDF

Solomon D., Lehmann J., Tekalign M., Fritzsche F., Zech W., 2001. Sulfur fractions in particle-size separates of the subhumid Ethiopian highlands as influenced by land use changes. Geoderma 102:42-59.

Stevenson F.J., Cole M.A., 1999. Cycles of soil: Carbon, nitrogen, phosphorus, sulfur, micronutrients. John Wiley \& Sons, Inc., New York, NY, USA.

Tabatabai M.A., Bremner J.M., 1972. Forms of sulfur and carbon, nitrogen and sulfur relationships in Iowa soils. Soil Sci. 114:380-386.

Wang J., Solomon D., Lehmann J., Zhang X., Amelung W., 2006. Soil organic sulfur forms and dynamics in the Great Plains of North America as influenced by long-term cultivation and climate. Geoderma 133/3-4:160-172.

Zhao F.J., Wu J., McGrath S.P., 1996. Soil organic sulphur and its turnover. In: A. Piccolo (ed) Humic Substances in Terrestrial Ecosystems. Elsevier, Amsterdam, The Netherlands.

Zucker A., Zech W., 1985. Sulfur status of four uncultivated soil profiles in northern Bavaria. Geoderma 36:229-240. 